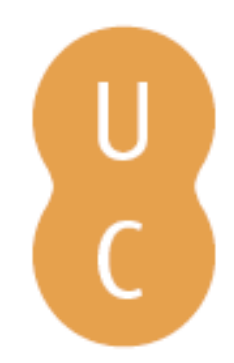

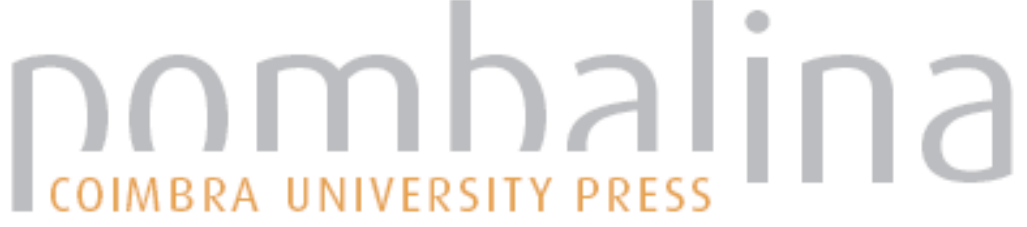

\section{The impact of climate change on fire weather of Daxing'anling}

Autor(es): $\quad$ Tian, Xiaorui; Shu, Lifu; Wang, Mingyu; Zhao, Fengjun

Publicado por: Imprensa da Universidade de Coimbra

URL

persistente: $\quad$ URI:http://hdl.handle.net/10316.2/44531

DOI: $\quad$ DOI:https://doi.org/10.14195/978-989-26-16-506_14

Accessed : $\quad$ 26-Apr-2023 11:25:28

A navegação consulta e descarregamento dos títulos inseridos nas Bibliotecas Digitais UC Digitalis, UC Pombalina e UC Impactum, pressupõem a aceitação plena e sem reservas dos Termos e Condições de Uso destas Bibliotecas Digitais, disponíveis em https://digitalis.uc.pt/pt-pt/termos.

Conforme exposto nos referidos Termos e Condições de Uso, o descarregamento de títulos de acesso restrito requer uma licença válida de autorização devendo o utilizador aceder ao(s) documento(s) a partir de um endereço de IP da instituição detentora da supramencionada licença.

Ao utilizador é apenas permitido o descarregamento para uso pessoal, pelo que o emprego do(s) título(s) descarregado(s) para outro fim, designadamente comercial, carece de autorização do respetivo autor ou editor da obra.

Na medida em que todas as obras da UC Digitalis se encontram protegidas pelo Código do Direito de Autor e Direitos Conexos e demais legislação aplicável, toda a cópia, parcial ou total, deste documento, nos casos em que é legalmente admitida, deverá conter ou fazer-se acompanhar por este aviso. 


\section{ADVANCES IN}

\section{FOREST FIRE RESEARCH}

\section{8}

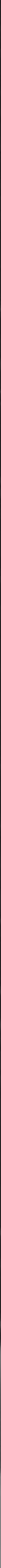




\title{
The impact of climate change on fire weather of Daxing'anling
}

\author{
Xiaorui Tian*, Lifu Shu, Mingyu Wang, Fengjun Zhao \\ Research Institute of Forest Ecology, Environment and Protection, Chinese Academy of Forestry, \\ State Forestry Administration's Key Open Laboratory of Forest Protection Beijing 100091, \\ China, \{tianxr@caf.ac.cn*\}
}

\begin{abstract}
There are amount of natural forests in Daxing'anling, and wildfires occurred in the region every year. Assessing the changes in fire weather in the future under multi-climate scenarios would contribute to our understanding of the influences of climate change for the region and provide a reference for applying adaptation measures for fire management. This study analysed the changes in fire weather indices and the fire season under four climate scenarios (RCP2.6, RCP4.5, RCP6.0, RCP8.5) for 2021-2050 using data from five global climate models together with observation data. The results showed that the analog data could project the average state of the climate for a given period but were not effective for simulating extreme weather conditions. Compared with the baseline period (1971-2000), the average temperature and annual precipitation were predicted to increase by $2.02^{\circ} \mathrm{C}-2.65{ }^{\circ} \mathrm{C}$ and $25.4-40.3 \mathrm{~mm}$ during 2021-2050, respectively. Multiple comparisons revealed that all of the indices would increase in 2021-2050 except for DC. The average FWI (fire weather index) was 4.53 at baseline, which would increase by $6.2 \%, 11.3 \%$, $10.6 \%$, and $11.2 \%$ under scenarios RCP2.6, RCP4.5, RCP6.0, and RCP8.5, respectively. SSR (seasonal severity rating) would increase by $5.5 \%, 16.2 \%, 15.1 \%$, and $17.2 \%$ in 2021- 2050 under scenarios RCP2.6, RCP4.5, RCP6.0, and RCP8.5, respectively. The DMC (duff moisture code), ISI (initial spread index), BUI (build-up index), FWI and SSR were predicted to increase significantly under scenarios RCP 4.5, RCP 6.0, and RC P8.5. Furthermore, days with high or higher fire danger rating were predicted to prolong 3-6 days in 2021-2050.
\end{abstract}

Keywords: climate change; forest fire; fire season; Daxing'anling

\section{Introduction}

The main features of climate change are warming and drying, and wildfires are closely linked these features (Hu et al. 2012; Flannigan et al. 2013; Sun et al. 2014). Fire activity is expected to increase in most regions worldwide with increasing temperature (Pechony and Shindell 2010). Fire is a natural disturbance in most forest ecosystems. The boreal forest is exhibiting responses to climate change. An average of 5-15 million hectares of boreal forest are burned each year in northern Siberia, Alaska and Canada, and serious fire years are occurring more frequently (Flannigan et al. 2009). Global warming will increase the potential for prolonged fire storms, causing fuel dryness (via increased evapotranspiration and drying of litter) and leading to more wildfires; i.e., fire severity is sensitive to global warming (Flannigan et al., 2013). Landscape fires are expected to change during the 21st century in response to multiple agents of global change. Important controlling factors include climate controls on the length and intensity of the fire season, fuel availability, and fire management, which are already anthropogenically perturbed at present and are predicted to change further in the future (Kloster et al. 2012). By 2030 and the end of the century, the number of forest fires in northern regions of Canada will increase by $30 \%$ and $75 \%$, respectively (Wotton \& Flannigan 2010). The fire season in western North America would prolong due to the advance of the spring snowmelt date and rising temperatures in spring and summer (Westerling et al. 2006; Running 2006). Spracklen et al. (2009) predicted that by the 2050s, the average annual burned area in the western United States will increase by 54\%, and forest fires in this region and in the Pacific Northwest area of the Rocky Mountains will increase by $78 \%$ and $175 \%$, respectively. Wildfires would increase by $179 \%$ in Portugal under a 
scenario of $2 \times \mathrm{CO}_{2}$, and burned areas would increase by $378 \%$, with an annual growth rate of 1.4 7.8\% (Carvalho et al. 2010).

The fire regime has been altered in Daxing'anling in the past fifty years and is expected to change continuously in the future. The fire season are getting prolonged and more lighting fires in the region. From 1961 to 2010, the annual rate of the increase in temperature in northeastern Inner Mongolia was $0.375^{\circ} \mathrm{C} / 10 \mathrm{a}$, and lightning fires increased significantly (Li et al. 2011). Forest fire danger also increased for the Greater Xing'an Mountains in Inner Mongolia, and the fire season has been extended, with more fires occurring in the forest in summer (Zhao et al. 2009). Fire control will become more difficult in the future (Di et al. 2011). The potential for fires in northeast China was expected to increase 10-18\% during the period 2071 - 2100, with the fire season being extended by 21-25 days (Tian et al. 2011). Liu et al. (2012) estimated that the density of fires in the boreal forest in northeastern China in the period from 2081 to 2100 will increase by $30 \%$ (CGCM3 B1 scenario) to 230\% (HadCM3 A2 scenario). Additionally, the annual days with high and very high fire danger ratings are expected to increase by 43 and 36 days under scenarios A2a and B2a in 2040-2069, respectively (Yang et al. 2010; 2012).

The RCP (Representative Concentration Pathways) climate scenario was adopted in the IPCC (Intergovernmental Panel on Climate Change) Fifth Assessment Report, which included four scenarios, RCP2.6, RCP4.5, RCP6.0, and RCP8.5. Each of these scenarios represents different conditions of forced radiation levels, $\mathrm{CO} 2$ concentrations, and their pattern of change (Van Vuuren $e t$ al., 2011). Scenarios RCP2.6, RCP4.5, RCP6.0, and RCP8.5 indicate increases in forced radiation of 2.6, 4.5, 6.0, and $8.5 \mathrm{~W} / \mathrm{m}^{2}$ in 2100 . RCP2.6 is a warming mitigation scenario (with forced radiation tending to decrease in 2100), and RCP4.5 and RCP6.0 represent stable situations (with the variation of forced radiation being relatively stable in 2100), while RCP8.5 is a scenario involving high greenhouse gas emissions (with forced radiation continuing to increase before 2100). In 2100, the $\mathrm{CO}_{2}$ concentration would reach 421, 538, 670, and 936 ppm under scenarios RCP 2.6, RCP 4.5, RCP 6.0, and RCP 8.5, respectively. Studying the effects on forest fire danger in Daxing'anling under the four RCP scenarios will contribute to a better understanding of fire activities in the future and provide a scientific reference for adaptation measures on fire management.

\section{Study area}

The study area is located in Daxing'anling, China (Figure 1), with a geographical range of 119.71 ${ }^{\circ}-127.02^{\circ} \mathrm{E}, 48.48^{\circ}-3.56^{\circ} \mathrm{N}$. The main forest type is a deciduous needle-leaved mixed forest dominated by Larix gemelini. Other common tree species that may be present include Pinus sylvestris, Betula platyphylla, Quercus mongolicus, Populus davidiana, and Salix matsudan.

There is a cold temperate continental monsoon climate. The winter is cold and long, while the summer is hot and short. The annual average temperature is $-2.8^{\circ} \mathrm{C}$, and annual precipitation is 450 $500 \mathrm{~mm}$ (Xu 1998). The soil is typically classified as a brown taiga coniferous forest soil. The topography is undulating, with an average elevation of $573 \mathrm{~m} \mathrm{ASL}$; however, higher hill tops can reach 1,528 $\mathrm{m}$ ASL. The region has an active fire season from March to October. 


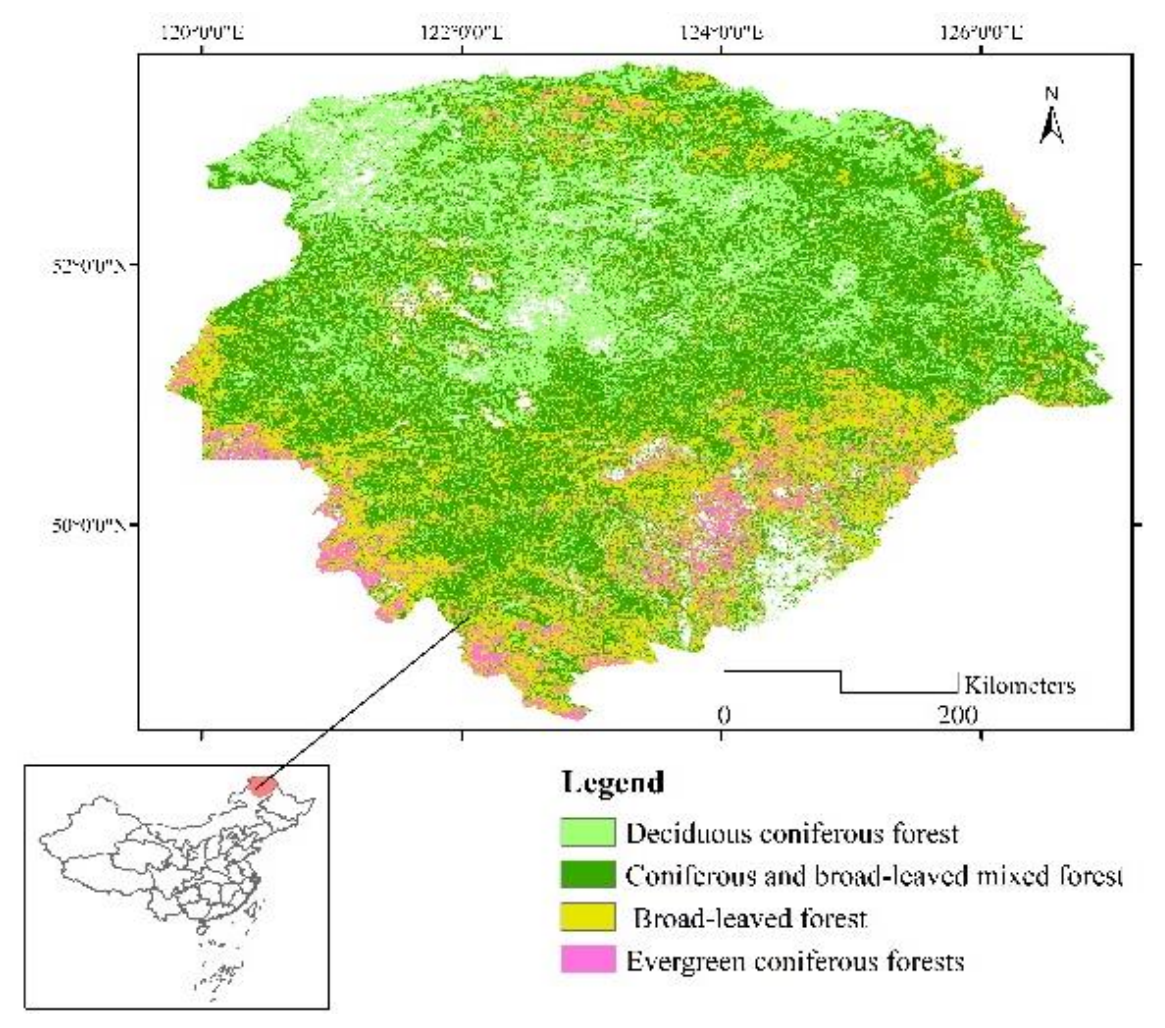

Figure 1 - Location and vegetation types of the study area

\section{Methods}

\subsection{Climate data for the four scenarios}

Climate data for the four scenarios under 1951-2050 were obtained from the Inter-Sectoral Impact Model Intercomparison Project (ISI-MIP) (http://www.isi-mip.org). These data were extracted by the Institute of Environment and Sustainable Development of Agriculture of the Chinese Academy of Agricultural Science and converted to ASCII code. The daily data included five meteorological elements (average temperature, maximum temperature, precipitation, average relative humidity, and average wind speed near the ground) for a global climate model (HadGEM2-ES) with four scenarios (RCP2.6, RCP4.5, RCP6.0, RCP8.5). The horizontal resolution of the data was $0.5^{\circ} \times 0.5^{\circ}$. The bilinear interpolation method was used to handle the original data, and statistical bias was processed based on the probability distribution (Piani et al. 2010; Hagemann et al. 2011; ISI-MIP 2013). Daily surface observation data from 10 weather stations for the baseline period (1971-2010) were used to adjust the simulation data (1951-2050).

\subsection{Forest fire danger index calculation}

The fire weather index (FWI) system requires inputs of data on the air temperature, relative humidity, precipitation and wind speed at noon. However, the regional climate model outputs only provided daily data. Therefore, the adjusted noon temperature, relative humidity, daily rainfall and average wind speed were used as the inputs to calculate fire weather indices for each grid. The system outputs three fuel moisture codes and three fire behavior indices. The fuel moisture codes include the fine fuel moisture code (FFMC), the duff moisture code (DMC), and the drought code (DC). The three fire behavior indices are the initial spread index (ISI), which is an indicator of the potential rate of fire spreading; the build-up index (BUI), representing total fuel available to a fire, which is used to perform correlations with fuel consumption; and the FWI which is a combination of the ISI and BUI, representing the intensity of a spreading fire. The FWI is used to indicate the overall fire danger to the public. The daily severity rating (DSR) is converted from FWI (Van Wagner 1970), which we averaged 
to obtain seasonal values (SSR, Seasonal Severity Rating) to assess fire severity for a fire season. The software ArcInfo 10.0 and ANUSPLIN (Hutchinson 1998) were used to interpolate the FWI system data to spatial surfaces at a $1 \times 1-\mathrm{km}$ resolution.

\subsection{Fire danger ratings}

The fire danger ratings for each FWI System component were classified as low, moderate, high, very high, or extreme based on the classification of danger classes for the FWI System. According to the distribution of the fire danger indices during 1987-2006 in Daxing'anling, the low, medium, high, very high and extreme fire danger ratings were found to correspond to FWI ranges of 0-2.5, 2.6-10.0, 10.1-18.0, 8.1-31.0 and >31.0, respectively (Tian et al. 2009).

\section{Results}

\subsection{Temperature and precipitation changes in the fire season}

Compared with the baseline period, the average annual temperature and precipitation in 2021-2050 were predicted to increase by $2.02-2.65{ }^{\circ} \mathrm{C}$ and $25.4-40.3 \mathrm{~mm}$ under scenarios RCP2.6, RCP4.5, RCP6.0, and RCP8.5 (Table 1). For 1951-2050, the annual mean temperature showed a gradual upward trend, but no significant trend for the precipitation (Figure 2). Compared with the observation data (1961-2010), the outputs from the global climate models exhibited less fluctuation, especially for precipitation. This indicated that regarding the analogy extreme values of temperature and precipitation in certain years, the projected values were lower than the observed values.

Compared with the baseline period, the daily average and maximum temperature and precipitation in fire season in $2021-2050$ would increase by $1.77-2.40^{\circ} \mathrm{C}, 1.72-2.28^{\circ} \mathrm{C}$ and $15.8-32.3 \mathrm{~mm}$. These results represented significant differences, and the corresponding $\mathrm{P}$ values for the t-test were $0.00,0.00$ and 0.01 , respectively.

Table 1 Changes in temperature and precipitation under four climate scenarios

\begin{tabular}{ccccccc}
\hline Scenario & Period & $\begin{array}{c}\text { Annual } \\
\text { average } \\
\text { temperature }\end{array}$ & $\begin{array}{c}\text { Average } \\
\text { temperature in } \\
\text { fire season }\end{array}$ & $\begin{array}{c}\text { Maximum } \\
\text { temperature in fire } \\
\text { season }\end{array}$ & $\begin{array}{c}\text { Annual } \\
\text { precipitation }\end{array}$ & $\begin{array}{c}\text { Precipitation in } \\
\text { fire season }\end{array}$ \\
\hline Observations & $1971-2000$ & -3.9 & 9.79 & 17.40 & 507.3 & 455.1 \\
Rcp2.6 & $2021-2050$ & -1.71 & 11.71 & 19.32 & 543.0 & 481.4 \\
Rcp4.5 & $2021-2050$ & -1.69 & 11.77 & 19.28 & 535.8 & 472.2 \\
Rcp6.0 & $2021-2050$ & -1.88 & 11.56 & 19.12 & 532.7 & 470.9 \\
Rcp8.5 & $2021-2050$ & -1.25 & 12.19 & 19.68 & 547.6 & 487.4 \\
\hline
\end{tabular}
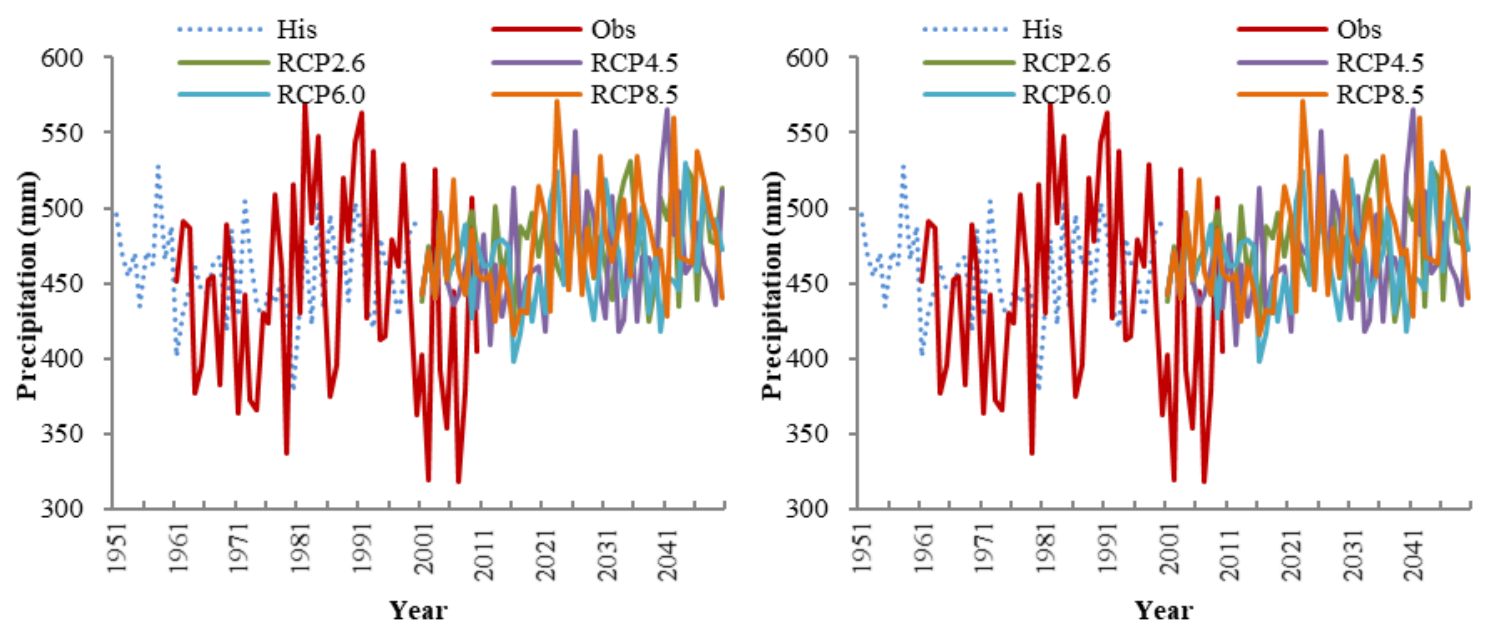

Figure 2 - Temperature and precipitation during the fire season in 1951-2050. (a) Average temperature in the fire season; (b) precipitation in the fire season. 


\subsection{Changes in fire weather indices}

The calculated average values for FFMC, DMC, DC, BUI, and FWI from the simulated climate data were higher than those from the observed data (Table 2), with DMC, DC, and BUI showing significant differences (with two-tailed $\mathrm{P}$ values from t-tests of $0.0216,0.0000$, and 0.0002, respectively). However, FFMC and FWI did not show significant changes (with two-tailed P values from t-tests of 0.1597 and 0.6840 , respectively). The average ISI and SSR values based on the simulated climate data were lower than the values calculated from the observed data, with ISI showing a significant difference $(\mathrm{P}=0.0073)$, whereas that for $\mathrm{SSR}$ was no significant $(\mathrm{P}=0.4847)$. The coefficients of variation (CV) for all of the fire danger indices calculated based on historical observations were greater compared with those based on simulated climate data. This indicated that the simulated data could describe the average state of the climate and fire danger in a given period very well, but not for extreme years. Therefore, the averages for 30 years are considered reliable to describe the possible status of fire danger in the future.

The curves for each fire weather index for 1971 - 2050 also showed that the volatility of the calculations based on simulated data was lower compared with that for observed data (Figure 3). In 2007, the indices calculated from observed data were significantly higher than in any other year because there were higher temperatures and less rainfall in that fire season. The average temperature was higher $14 \%\left(+1.4^{\circ} \mathrm{C}\right)$, and rainfall was $30 \%$ lower than the baseline values in 2000 , which was another anomalous season.

Table 2 - Comparison of the results calculated from the simulated and observed data for 1976-2000

\begin{tabular}{ccccccc}
\hline Index & Data & Average & Minimum & Maximum & Range & Coefficient of variation \\
& Source & & & & & \\
\hline \multirow{2}{*}{ BUI } & Observed & 29.7 & 17.2 & 41.6 & 24.4 & 0.185 \\
& Simulated & 35.8 & 32.1 & 41.2 & 9.1 & 0.063 \\
DC & Observed & 197.8 & 131.6 & 320.0 & 188.4 & 0.219 \\
& Simulated & 309.0 & 263.5 & 371.2 & 107.7 & 0.100 \\
DMC & Observed & 20.5 & 12.0 & 29.8 & 17.8 & 0.213 \\
& Simulated & 22.7 & 19.9 & 26.4 & 6.5 & 0.064 \\
\multirow{3}{*}{ FFM } & Observed & 0.8 & 0.3 & 1.6 & 1.3 & 0.407 \\
& Simulated & 0.8 & 0.6 & 1.1 & 0.5 & 0.132 \\
\multirow{2}{*}{ FWI } & Observed & 69.3 & 64.0 & 73.6 & 9.5 & 0.028 \\
& Simulated & 68.7 & 67.1 & 71.0 & 3.9 & 0.014 \\
& Observed & 4.2 & 2.2 & 6.5 & 4.3 & 0.240 \\
& Simulated & 4.3 & 3.7 & 4.9 & 1.3 & 0.071 \\
& Observed & 1.9 & 1.3 & 2.7 & 1.4 & 0.181 \\
\hline
\end{tabular}

Note: Here, we only used the data for 1976-2000, due to missing relative humidity data in 1971-1975. 

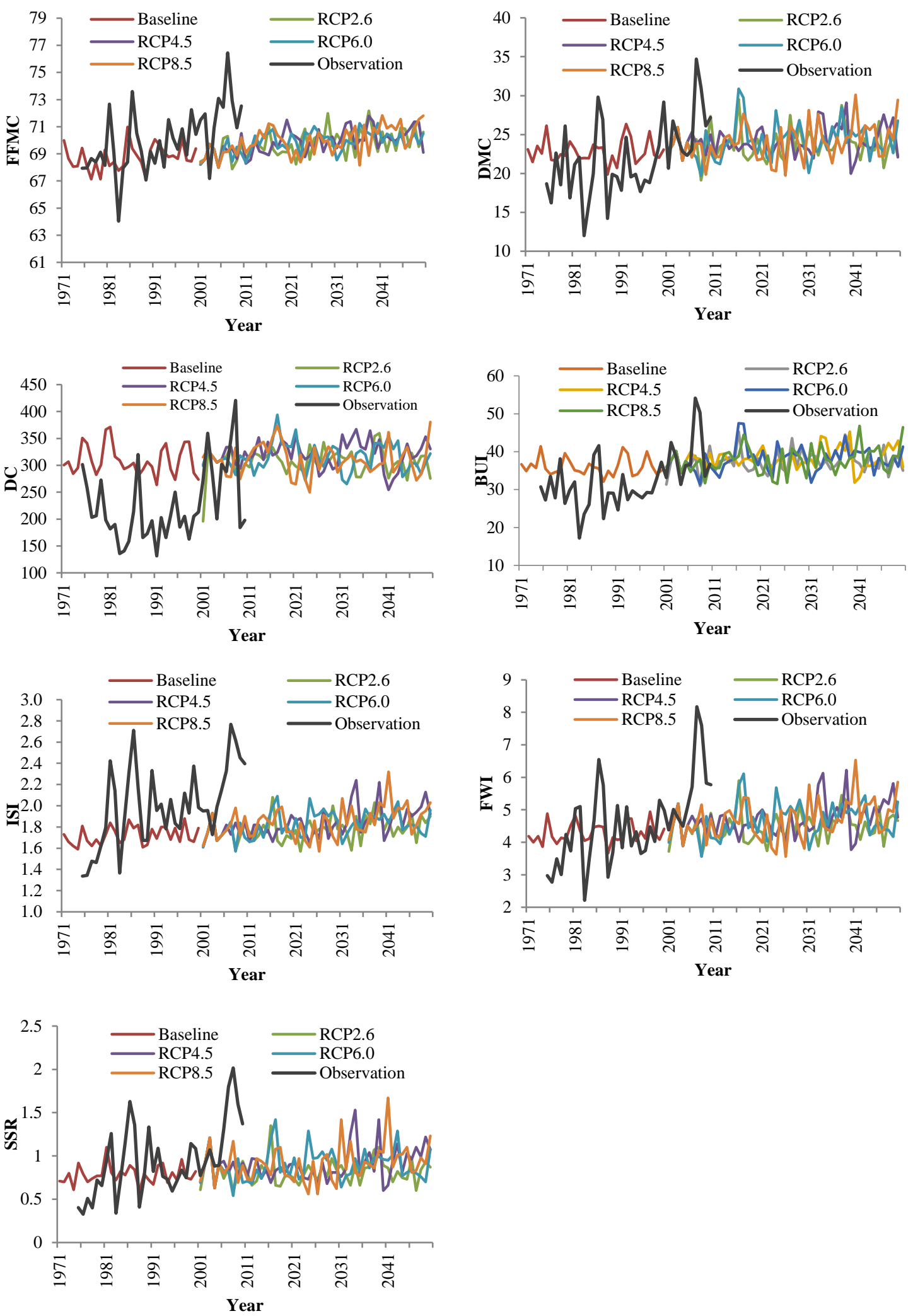

Figure 3 - The fire weather indices in 1971 - 2050

Based on the consistency of the data, we used the results calculated from the simulated data from the GCM at baseline to analyse the changes in the fire weather indices for 2021 - 2050. Multiple comparisons revealed that all of the indices would increase in 2021 - 2050 except for DC (Table 3). FFMC would increase significantly for all four scenarios, but DMC, ISI, BUI, FWI and SSR would 
increase significantly only for scenarios RCP4.5, RCP6.0, and RCP8. DC would not change significantly under any scenario.

Table 3 - Multiple comparisons of the fire weather indices for 2021- 2050 and the baselinefor the four climate scenarios

\begin{tabular}{cclll}
\hline Fire weather indices & Rcp2.6 & Rcp4.5 & Rcp6.0 & Rcp8.5 \\
\hline FFMC & $1.3360^{*}$ & $1.4807^{*}$ & $1.4000^{*}$ & $1.3953^{*}$ \\
DMC & 0.9713 & $1.4637^{*}$ & $1.5767^{*}$ & $1.4457^{*}$ \\
DC & -0.7983 & 11.3537 & 4.3327 & -2.4017 \\
ISI & $0.0867^{*}$ & $0.1613^{*}$ & $0.1367^{*}$ & $0.1440^{*}$ \\
BUI & 1.4873 & $2.4080^{*}$ & $2.2763^{*}$ & $1.9697^{*}$ \\
FWI & 0.2603 & $0.5223^{*}$ & $0.4673^{*}$ & $0.4847^{*}$ \\
SSR & 0.042 & $0.1453^{*}$ & $0.1360^{*}$ & $0.1487^{*}$ \\
\hline
\end{tabular}

Note: * indicates that the mean difference was significant at $\alpha=0.05$.

The average FWI was 4.53 (range, 1.68 to 6.78 ) at baseline, which would increase by $6.2 \%, 11.3 \%$, $10.6 \%$, and $11.2 \%$ under scenarios RCP2.6, RCP4.5, RCP6.0, and RCP8.5, respectively (Figure 4). For scenario RCP2.6, FWI would increase significantly in central areas, whereas it would increase significantly in the southwest under the other three scenarios. FWI would increase by more than $15 \%$ in some areas under scenario RCP8.5.

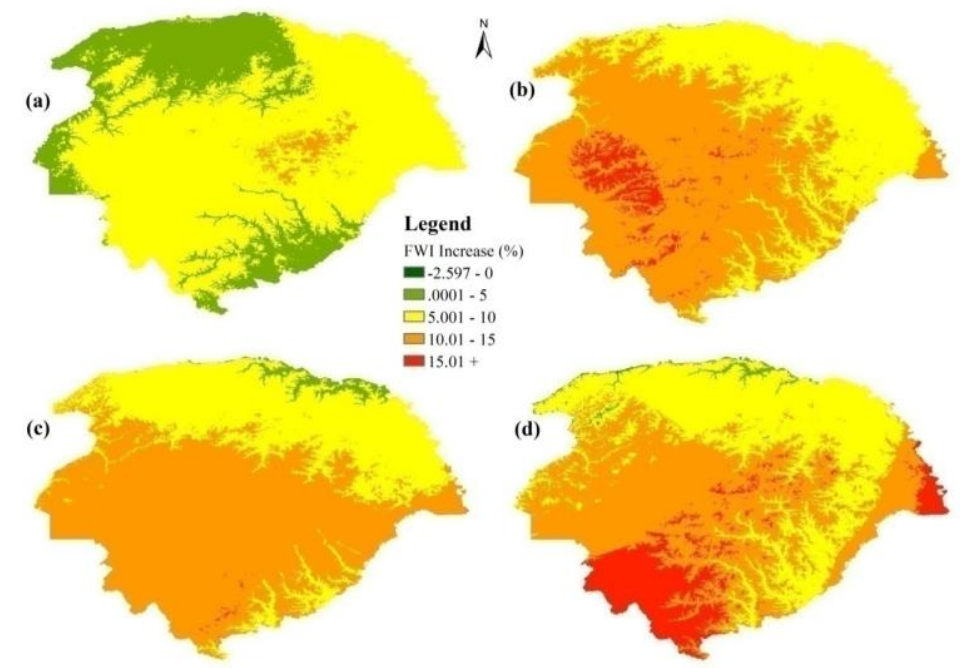

Figure 4 - Increment of FWI for 2021- 2050. (a), (b), (c) and (d) are maps of the FWI increment (\%) under scenarios RCP2.6, RCP4.5, RCP6.0, and $R C P 8.5$, respectively.

\subsection{Fire weather severity analysis}

At baseline, the average SSR was 0.86 (range from 0.03 to 1.61 ), with SSR increasing gradually from the northeast to the southwest. SSR would increase by $5.5 \%, 16.2 \%, 15.1 \%$, and $17.2 \%$ in 2021 2050 under scenarios RCP2.6, RCP4.5, RCP6.0, and RCP8.5, respectively.

There were small parts of the central region where SSR would increase by over $10 \%$ under scenario RCP2.6, while an SSR increment of greater than $10 \%$ was predicted in most of the region under the other three scenarios, with this change being more significant (over 20\%) in the southwest (Figure 5). Under scenarios RCP4.5, RCP6.0, and RCP8.5, SSR would increase more in 2021-2050 where the higher SSR values occurred at baseline, though a different result was obtained for scenario RCP2.6. 


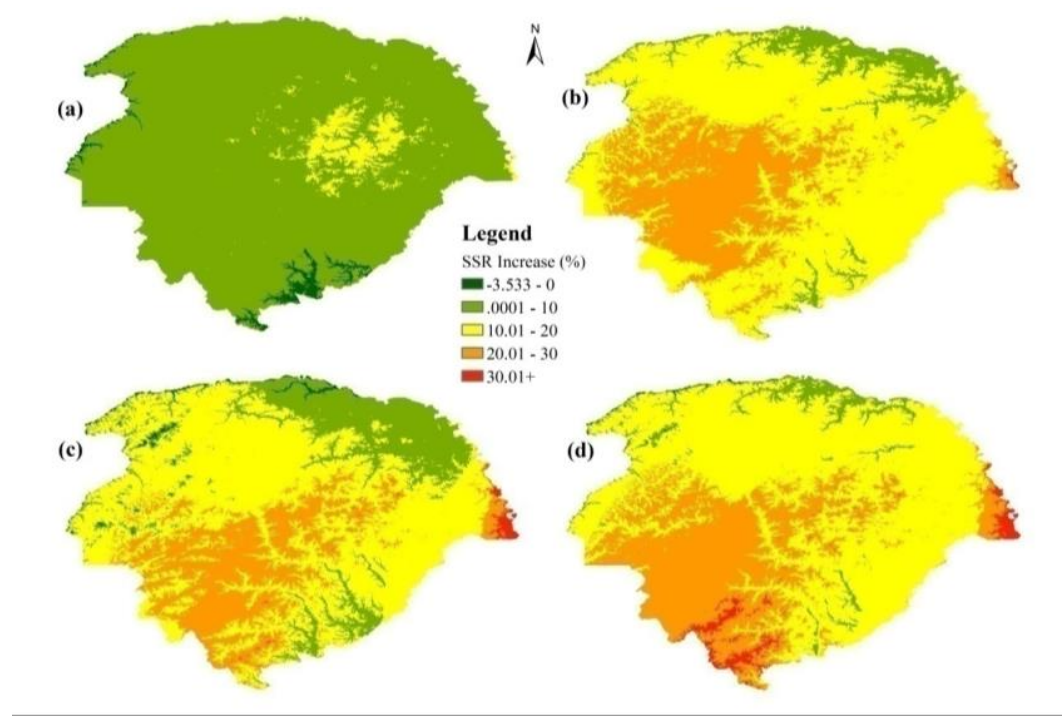

Figure 5 - SSR increment in 2021-2050. (a) Scenario RCP2.6; (b) Scenario RCP4.5; (c) Scenario RCP6.0; (d) Scenario RCP8.5.

\subsection{Changes in the number of days with high or higher fire danger ratings}

At baseline, the number of days with high, very high, and extreme fire danger ratings was 37.7 (range from 13 to 59 days), with this number being smaller in the north and greater in the south. Compared with the baseline period, the number of days with high or higher fire danger rating would increase by 3.3, 5.6, 5.6 and 5.7 days in 2021- 2050 under scenarios RCP2.6, RCP4.5, RCP6.0, and RCP8.5, respectively. The corresponding ranges were 0.8-5.8, 2.2-9.1, 0-10.6, and 2.4-11.8 days (Figure 6). The number of days with high or higher fire danger rating would increase least under scenario RCP2.6 and most under scenario RCP8.5. Under scenario RCP4.5, the change in the number of days would increase gradually from the northeast to the southwest, while increasing from north to south for scenarios RCP6.0 and RCP8.5.

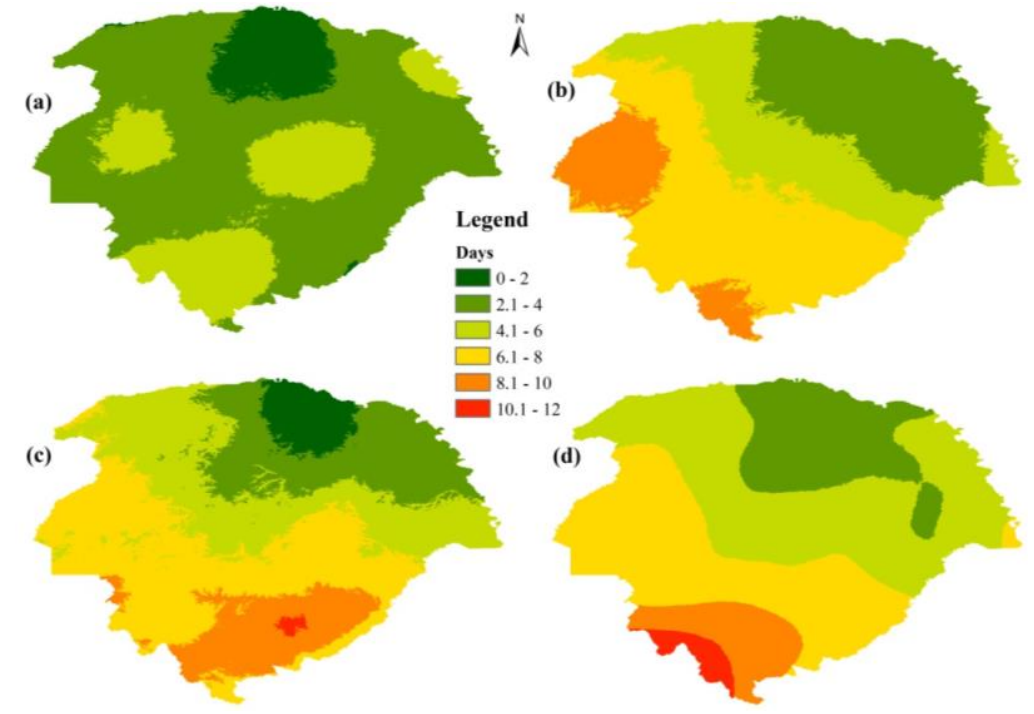

Figure 6 - The change in the number of days with high or higher fire danger ratings in 2021 - 2050. (a) Scenario RCP2.6; (b) Scenario RCP4.5; (c) Scenario RCP6.0; (d) Scenario RCP8.5.

\section{Discussion}

Previous studies have shown that there is significant positive correlation between the burned area and DMC, ISI, and FWI in Daxing'anling (Tian et al. 2013). The relationship between the FWI ratio 
and potential burned areas is $1: 1$, and an increase in the FWI ratio would cause a similar increase in the burned area (Flannigan et al. 2001). Therefore, if it is assumed that the fire management capacity will not change significantly in the near future, we can conclude that the potential burned areas in Daxing'anling will increase by 6-11\% in 2021 -2050 compared with baseline. Past studies for the region have indicated that fire danger will increase to some degree (Yang et al. 2010; Tian et al. 2011; Liu et al. 2012). However, these studies were based on SEARS scenarios. Van Vuuren et al. (2011) considered scenario RCP2.6 to be the most likely scenario in the future. Under this scenario, the seasonal severity rating for the region would increase by more than $5 \%$.

It was found that $77.5 \%$ of all fires occurred during weather associated with a high or higher fire danger class in Daxing'anling (Tian et al. 2009). Thus, the length of the period of weather associated with a high or higher fire danger would have a greater impact on fire activity for the region. We projected that this period would increase by 3-6 days (8.7-15.1\%) in 2021-2050. Our results showed a large difference from those of Yang et al. (2010; 2012), who projected that the average number of days with a high and very high fire danger would increase by 43 and 36 days in 2040-2069 for scenarios $\mathrm{A} 2 \mathrm{a}$ and $\mathrm{B} 2 \mathrm{a}$, respectively. The main reasons for this difference were the differences in the climate scenarios, the threshold values for fire danger ratings, and the adjusted methods for the climate data. In this study, the thresholds of the fire danger ratings were derived from historical observations (Tian et al. 2009), and the simulated data were adjusted with the observations. As the simulation data did not reflect extreme weather well, the number of days with a high or higher fire danger rating may be fewer than indicated by the actual data.

We did not consider changes in fuel, ignition sources, and fire management capabilities in this study. However, these factors are currently considered to be unlikely to undergo fundamental changes in the next 30 years. Therefore, the uncertainty caused by these factors would have a limited influence on the conclusion.

\section{Conclusion}

GCM-simulated data can describe the average climate state for a given period well, but they cannot simulate extreme weather conditions. It would be reliable to describe the state of the climate and forest fire danger over an average of 30 years. Compared with the baseline period, temperature is predicted to increase significantly in 2021-2050, whereas precipitation is not predicted to show a significant change. FWI is predicted to increase by $6.2-11.2 \%$ in 2021- 2050. DMC, ISI, BUI, FWI, and SSR are predicted to increase significantly under scenarios RCP4.5, RCP6.0, and RCP8.5. The number of days with a high or higher fire danger rating are predicted to increase by 3-6 days, and the increase is predicted to be remarkable in the south for scenarios RCP4.5, RCP6.0, and RCP8.5.

\section{Acknowledgements}

This study received financial support from Project (31270695) of the National Natural Science Foundation of China and the National Science and Technology Support Plan (2018YFD0600205).

\section{References}

Carvalho A, Flannigan M, Logan K, Gowman L, Miranda A, Borrego C (2010) The impact of spatial resolution on area burned and fire occurrence projections in Portugal under climate change. Climate Change 98:177-197

Di X, Li Y, Sun J, Yang G (2011) Dynamics of forest fire weather indices in Tahe County of Great Xing'an Mountains region, Heilongjiang Province. Chinese Journal of Applied Ecology 22(5):1240-1246 
Flannigan MD, Krawchuk MA, de Groot WJ, Wotton BM, Gowman LM (2009) Implications of changing climate for global wildland fire. International Journal of Wildland Fire 18: 483-507.

Flannigan MD, Wotton BM (2001) Climate, weather and area burned. Forest Fires: Behavior \& Ecological Effects (Eds. Johnson EA, Miyanishi K), Academic Press, New York, 335-357

Hagemann S, Chen C, Haerter JO, Heinke J, Gerten D, Piani C (2011) Impact of a Statistical Bias Correction on the Projected Hydrological Changes Obtained from Three GCMs and two Hydrology Models. Journal of Hydrometrorology 12:556-578.

$\mathrm{Hu} \mathrm{H}$, Wei S, Sun L (2012) Estimation of carbon emissions due to forest fire in Daxing'an Mountains from 1965 to 2010. Chinese Journal of Plant Ecology 36(7): 629-644

ISI-MIP (2013) The inter-sectoral impact model intercomparison project design and simulation protocol (V2.3). http://www.ncbi.nlm.nih.gov/pmc/articles/PMC3948262/pdf/pnas.201312330.pdf

Li X, Wu W, Zhang C, Guo R (2011) Influence of climate change on northeastern of Inner Mongolia grassland forest fire. Journal of Arid Land Resources and Environment 25(11): 114-119

Piani C, Weedon GP, Best M, Gomes SM, Viterbo P, Hagemann S, Haerter JO (2010) Statistical bias correction of global simulated daily precipitation and temperature for the application of hydrological models. Journal of Hydrometrorology 395: 199-215

Running SW (2006) Climate change : Is global warming causing more larger wildfires. Science 313(5789): 927-928

Spracklen DV, Mickley LJ, Logan JA, Hudman RC, Yevich R, Flanning MD, Westerling AL (2009) Impacts of climate change from 2000 to 2050 on wildfire activity and carbonaceous aerosol concentrations in the western United States. Journal of Geophysical Research 114, D20301, DOI:10.1029/2008JD010966

Sun Long, Wang Q, Wei S (2014) Response Characteristics and Prospect of Forest Fire Disasters in the Context of Climate Change in China. Journal of Catastrophology 29(1): 12-17

Tian X, Shu L, Zhao F, Wang M, Mcrae DJ (2011) Future Impacts of Climate Change on Forest Fire Danger in Northeastern China. Journal of forestry research 22(3): 437-446

Tian X, Shu L, Wang M, Zhao F (2009) Spatial and Temporal Distribution of Lightning Fire and Forecasting Model for Daxing'anling Region. Forest Research 22(1): 14-20

van Vuuren DP, Edmonds J, Kainuma M, Riahi K, Thomson A, Hibbard K, Hurtt GC, Kram T, Krey V, Lamarque JF, Masui T, Meinshausen M, Nakicenovic N, Smith SJ, Rose SK (2011) The representative concentration pathways: an overview. Climatic Change 109: 5-31

Westerling AL, Hidalgo HG, Cayan DR, Swetnam TW (2006) Warming and earlier spring increase western U.S. forest wildfire activity. Science 313(5789): 940-943

Wittrock V, Wheaton E (1997) Climate Variations, Fire Characteristics and Budget Implications: Preliminary Analysis of their Relationships. Saskatchewan Research Council (SRC), Saskatoon, Saskatchewan. SRC Publication No. R-1550-2-E-97

Yang G, Di X, Zeng T, Shu Z, Wang C, Yu H (2010) Prediction of area burned under climatic change scenarios: A case study in the Great Xing'an Mountains boreal forest. Journal of Forestry Research 2l(2): 213-218

Yang G, Shu L, Di X (2012) Prediction on the changes of forest fire danger rating in Great Xing'an Mountain region ofNortheast China in the 21 st century under effects of climate change. Chinese Journal of Applied Ecology 23(12): 3236 -3242

Zhao F, Shu L, Di X, Tian X, Wang M (2009) Changes in the occurring date of forest fires in the inner Mongolia Daxing'anling forest region under global warming. Scientia Silvae Sinicae 45(6):166172 